\title{
Synthesis and Characterization of Pumice-Supported nZVI for Removal of Copper from Waters
}

\author{
Bilgehan Ilker Harman ${ }^{1}$ and Mesut Genisoglu ${ }^{2}$ \\ ${ }^{1}$ Technical Science Vocational School, Suleyman Demirel University, 32260 Isparta, Turkey \\ ${ }^{2}$ Department of Environmental Engineering, Suleyman Demirel University, 32260 Isparta, Turkey \\ Correspondence should be addressed to Bilgehan Ilker Harman; ilkerharman@sdu.edu.tr
}

Received 14 January 2016; Revised 11 March 2016; Accepted 21 March 2016

Academic Editor: Santiago Garcia-Granda

Copyright (C) 2016 B. I. Harman and M. Genisoglu. This is an open access article distributed under the Creative Commons Attribution License, which permits unrestricted use, distribution, and reproduction in any medium, provided the original work is properly cited.

\begin{abstract}
The target of this work was to study the synthesis and characterization of pumice-supported nanoscale zero-valent iron (nZVI) and the effectiveness of nZVI coated pumice to remove copper from water. The impacts of pumice dose, pumice surface chemistry, $\mathrm{pH}$, and water source on copper removal were studied. Natural pumice particles were used as granular support media and coated with nZVI. Results of nZVI coated pumice characterization showed nZVI coated successfully on pumice surface being proved with characterization methods such as SEM-EDS, XPS, and XRF. nZVI coating overwhelmed the surface chemistry properties of the underlying pumice particles. Higher surface areas and more iron content were obtained in nZVI coated pumice. nZVI coating significantly increased copper uptake compared to uncoated particles. High removal capacity has been observed for all tested $\mathrm{pH}$ values. Control experiments indicated that nZVI bound on pumice surfaces is stable at $\mathrm{pH}$ values of typical natural waters. The nZVI coated pumice was found to be effective in removing copper from waters having a wide range of specific UV absorbance (SUVA) values. Overall, the results indicated that nZVI coated pumice particles are maybe alternative adsorbents to remove copper.
\end{abstract}

\section{Introduction}

Heavy metals, which are listed among the most toxic pollutants, contaminate water sources and cause environmental problems $[1,2]$. The main sources of heavy metals are the industrial waste from processes such as electroplating, leather tanning, textile, paint, steel production, mining, and chemical production as well as agricultural activities $[1,3,4]$.

Exposure to heavy metals in humans is primarily in the form of contaminated foods, drinking water, and skin and lungs absorption [1]. Copper is an essential micronutrient in small amounts for humans, animals, plants, and microorganisms [5]. However, the presence of large amounts of heavy metals in the environment may be harmful to humans and living organisms [6]. The nonbiodegradable nature of metals and their accumulation in the bodies of living things can cause a variety of diseases and disorders [1, 6, 7]. Excess copper is known to cause itching and dermatization, possible changes in liver and kidney, and gastrointestinal system, cataracts, Wilson's disease, hypoglycemia, and dyslexia [68]. Excess copper uptake increases the blood pressure and respiratory rate and causes kidney, liver, and central nervous system damage $[5,9,10]$. While the maximum permissible concentration of copper in drinking water is limited to $1.3 \mathrm{mg} / \mathrm{L}$ by the EPA, this value is determined as $2 \mathrm{mg} / \mathrm{L}$ under the Regulation on Water Intended for Human Consumption in the Turkish legislation $[11,12]$. The release of toxic ions into the water leads to major environmental problems. Therefore, effective water treatment technologies that eliminate toxic ions from water should be developed for clean and safe water supply containing metal ions only at allowable levels [13].

The methods used for heavy metal removal are chemical precipitation, ion exchange, filtration, membrane separation, and adsorption. Among these, adsorption is known to be an effective method in removing dissolved metal ions in water [1]. Adsorption is the most widely used process due to the simplicity of its operation and low implementation costs when compared with other treatment methods [1]. Adsorbent 
substances, most commonly used to remove heavy metals from water, are activated carbon, ion exchange resins, red clay, activated alumina, biomass, and chitosan and carbon nanotubes [7, 13-19].

Pumice stone has been tested and used in various environmental applications mainly as adsorbent, filtration media, biofilm, or catalyst support, similar to the uses of sand. Pumice is a light and very porous material formed during volcanic eruptions [20]. Pumice is a low-cost adsorbent effective in the removal of heavy metals [21, 22]. Moreover, it provides an increase in the adsorption capacity by providing more surface area after coating [20, 22].

As it is well known, nanoscale zero-valent iron (nZVI) is effective in removing pollutants from the water due to its very small particle size, larger surface area, and high reactivity $[21,23]$. However, because of its easy oxidation to iron oxide in an aerobic environment, the application of nZVI is limited to anaerobic medium $[21,24]$. When the surface of the nZVI is coated with the oxidized precipitate nZVI, the activity of the nZVI is substantially undermined causing a decrease in the speed and the effect of the reaction [25]. nZVI is also easily agglomerated which restricts its field of application [21, 26]. To overcome this disadvantage, the immobilization of nZVI on a support material (e.g., active carbon, metallic oxides, and zeolites) is regarded as an effective application [25, 27, 28]. In recent years, pillared clay, bentonite, kaolin, bamboo, and chitosan is widely used to improve the dispersibility of nZVI $[21,29-32]$. The advantages of pumice particles are that they are highly porous and have higher surface areas, which may immobilize more amounts of $\mathrm{nZVI}$, thus providing more adsorption sites as an alternative to other support materials $[21,33,34]$.

The main objective of this study is (i) developing a new material (to improve the higher surface area and adsorption capacity) through the coating of pumice surface with nZVI to combine advantages of pumice (low cost and natural material) and nZVI (high adsorption/oxidation capacity) and (ii) investigating copper removal from natural and model waters via adsorption through the use of pumice-supported nZVI (P-nZVI). Also, the effects of the $\mathrm{pH}$ of the solution, the adsorbent dosage, and the background impurities on copper removal were examined under different conditions. To our knowledge, nZVI coated pumice particles for copper adsorption in waters have not been investigated systematically before.

\section{Materials and Methods}

2.1. Materials. Of the chemicals used for coating, sodium borohydride (fine granular for synthesis) and iron (III) chloride (anhydrous for synthesis) were supplied from Merck, whereas ethanol (absolute HPLC grade) was supplied from J.T.Baker. As for support layer, Isparta pumice (IP) from Isparta, Turkey, was used in this study. IP samples were supplied from Pumice Research and Application Center operating under Suleyman Demirel University. Copper sulfate pentahydrate used for preparing the model solutions was supplied from Merck, while humic acid (50-60\%) was supplied from Acros Organics. Standard solution used for copper analysis (single element standard) was supplied from Perkin Elmer.

2.2. Synthesis of Pumice-Supported nZVI. The IP raw samples were ground by primary crusher (hammer type) and then sieved to particle size of $<63$-micron fraction. IP samples were subjected to acid activation in order to increase the effectiveness of the coating. For acid activation $<63$-micron IP was pretreated in $1 \mathrm{M} \mathrm{HCl}$ for 24 hours and stirred at regular intervals. After 24 hours, IP samples were rinsed with distilled and deionized water (DDW) several times until $\mathrm{pH}$ reached neutral levels ( $\mathrm{pH}$ was measured at 6.7). Acid Activated IP (AAIP) was dried at $70^{\circ} \mathrm{C}$ in the oven and was prepared for nZVI coating. The coating process was performed according to Liu et al. in [34]. The pumice-supported nanoscale zero-valent iron (P-nZVI) was produced according to conventional liquid phase method in which the pumice was used as a support layer and borohydride $\left(\mathrm{NaBH}_{4}\right)$ was used as a reduction agent for iron ions $\left(\mathrm{FeCl}_{3}\right)[30,32,34,35]$. After $3.36 \mathrm{~g}$ pumice was introduced into the three-neck flask, the iron solution obtained by dissolving $0.81 \mathrm{~g}$ ferric chloride in ethanol-water solution $(100 \mathrm{~mL}, 8: 1 \mathrm{v} / \mathrm{v})$ was added. After being stirred for 1 hour, a freshly prepared $\mathrm{NaBH}_{4}$ solution $\left(0.95 \mathrm{~g}\right.$ in $\left.100 \mathrm{~mL} \mathrm{NaBH}_{4}\right)$ was added dropwise with a flow rate of 50-60 drops per minute and was subjected to continuous mixing for 60 minutes. Solution was homogenized with a $37 \mathrm{kHz}$ sonification applied every 10 minutes. The theoretical mass fraction of the synthesized nZVI is P-nZVI 7.7\% [34]. The phase separation of the liquid solution with the synthesized materials was performed by centrifugation at $8000 \mathrm{rpm}$ for 10 minutes. After the top phase is taken out, P-nZVI precipitated at the bottom was dried in porcelain crucible at $65^{\circ} \mathrm{C}$ all night long. P-nZVI was preserved in a dry amber flask. All processes applied for the synthesis were carried out in nitrogen atmosphere.

2.3. Adsorption Tests. Kinetic studies were conducted to determine the optimum reaction time prior to adsorption test (reaction time: 10, 20, 30, 60, 120, 240, 480, 720, and 1440 minutes). The equilibrium time for adsorption studies was identified as 240 minutes in the kinetic study. Copper removal tests were conducted at 3000 ppb copper concentration with DDW water, Egirdir Lake drinking water, and model humic acid solution, using the bottle point adsorption method at $150 \mathrm{rpm}$

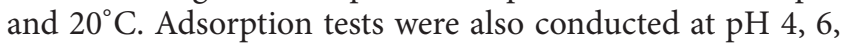
and 10 , respectively, in order to determine the effect of $\mathrm{pH}$ on removal. In order to determine the effect of adsorbent concentration on removal, adsorption tests were conducted at P-nZVI/L concentrations of $0,100,250,500,750,1000,1500$, 2000, and $3000 \mathrm{mg}$. To determine the effect of the coating, each removal test was repeated with the original IP. Samples were separated from P-nZVI by centrifugation at $8000 \mathrm{rpm}$.

2.4. Analytical Techniques. The concentrations of $\mathrm{Cu}$ in the solutions were measured using an inductively coupled plasma-mass spectrometry (ICP-MS, NexION 300X, PE). The morphological analysis of P-nZVI was performed using a scanning electron microscope (SEM) with an energydispersive X-ray spectrometer (EDS) (SEM/EDS, XL 30S 
FEG, Philips). Microscope images were obtained using a polarized light microscopy (PLM, BX51TF, Olympus) at 200x magnification. An X-ray photoelectron spectroscope (XPS) measured the surface composition and the elements valence of P-nZVI required Physical Electronics (VersaProbe II). Zeta potential was measured by Zetasizer instrument (nano-ZS90, Malvern). The surface areas of pumice and P-nZVI were measured using the BET- $\mathrm{N}_{2}$ adsorption method (BrunauerEmmett-Teller isotherm) using the Accelerated Surface Area and Porosimetry Analyzer (Gemini V, Micromeritics). Xray fluorescence (XRF) measurement was performed with a SPECTRO iQ II system. The thermal stability of P-nZVI was determined using a thermogravimetric analyzer (Diamond TG/DTA, PE). The FTIR spectra of pumice and P-nZVI were obtained using a Fourier Transform Infrared Spectroscopy (FTIR, Spectrum Two IR, PE). Samples were prepared by dilution with $1 \%(\mathrm{w} / \mathrm{w}) \mathrm{KBr}$ powder.

\section{Results and Discussions}

\subsection{Material Characterization}

3.1.1. SEM/PLM Imaging and EDS Analysis. SEM/EDS was performed in order to determine the morphology and mineral composition of bare and nZVI coated pumice. SEM images of bare pumice and nZVI coated pumice at different magnitudes are shown in Figures 1(a) and 1(c) and Figures 1(b) and 1(d), respectively. It is clearly seen in Figure 1(b) that the nZVIs on the surface of nZVI coated pumice are distributed in a heterogeneous manner and that the coating was successful. It is worth taking note that nZVIs appear bound to each other in the form of a chain across the surface of pumice especially in the image captured from the nZVI coated pumice using a BSED detector (Figure $1(\mathrm{~d})$ ). When the literature is examined the chain-like structure of nZVI particles on different materials was documented by many researchers with SEM images [21, 26, 30, 32, 36]. Natural materials such as zeolite, kaolin, and sepiolite were used in enhancing the dispersibility of nZVI particles because of a decrease in aggregation and an increase in mechanical strength [37-41]. Pumice particles were selected as supported media for coating because of porous structure, higher surface area, natural occurrence, and being locally in Isparta region.

The particle diameter of nZVI is estimated to be in the nanometer level in Figure 1(d). As such, in their study, Liu et al. [34] measured the particle diameter of the nZVI they obtained with the same method of nZVI synthesis used in this study, approximately $31 \mathrm{~nm}$. Üzüm et al. [32] on the other hand demonstrated that nZVI diameters ranged between 10 and $80 \mathrm{~nm}$. The mineral surface composition of the pumice and nZVI coated pumice was determined through EDS analysis. The results obtained by the EDS analysis are given in Table 1 . While elements like $\mathrm{Si}, \mathrm{Al}, \mathrm{O}$, and $\mathrm{C}$ are generally found in the EDS analysis performed on the bare pumice, as expected, aside from these elements, Fe was also detected in the nZVI coated pumice. The iron content of the bare pumice was $2.03 \%$ in terms of weight, while the iron content of the nZVI coated pumice was $41.98 \%$. These results showed that $\mathrm{nZVI}$ coating procedure has been successful. nZVI/iron
TABle 1: Chemical composition of bare pumice and P-nZVI obtained by EDS analysis.

\begin{tabular}{lccccccc}
\hline & \multicolumn{7}{c}{ Elements (wt\%) } \\
& $\mathrm{O}$ & $\mathrm{Fe}$ & $\mathrm{C}$ & $\mathrm{Si}$ & $\mathrm{Al}$ & $\mathrm{K}$ & $\mathrm{Na}$ \\
\hline Bare pumice & 44.93 & 2.03 & 17.79 & 17.81 & 5.84 & 3.53 & 2.38 \\
P-nZVI & 37.68 & 41.98 & 7.33 & 4.24 & 1.39 & 0.69 & 4.70 \\
\hline
\end{tabular}

oxide sites on pumice surface adsorbed/oxidized copper in a few minutes. However, Yigit and Tozum [42] reported that the coating of pumice did not increase the iron content. The SEM images give the information only about surface morphology. It is clearly stated in some studies that nZVI reaction capacity is decreased because nZVI is itself very quickly agglomerated [26]. Xi et al. [43] reported that synthesized nZVI alone was agglomerated providing SEM images. In this context, nZVI should be immobilized on granular support media such as sand, pumice, and zeolite. The porous structure of original pumice particles and uniform coverage of these pores by the nZVI coating can be clearly seen from SEM images. Coverage/filling of these pores significantly enhanced their adsorptive copper removal.

Also images were captured with polarized light microscopy (PLM) as part of the characterization studies and the difference of appearance due to crystallized structure between the bare pumice and the nZVI coated pumice is shown in Figures 1(e) and 1(f). Vitreous silica crystallization is clearly seen in the images from bare pumice captured by the PLM image, whereas the transparency is replaced with a black texture in the PLM images of the nZVI coated pumice. This is because, during coating, the glassy structure of pumice surface is lost as it is covered with nZVI.

3.1.2. XPS Scanning. Surface analyses of the pumice and nZVI coated pumice are characterized by XPS. The spectrums of bare pumice and the nZVI coated pumice obtained via XPS are shown in Figures 2(a) and 2(b), respectively. A detailed analysis of XPS results reveals that, similar to the SEM-EDS results, the elements detected in the surface of the bare pumice were $\mathrm{O} 1 \mathrm{~s}, \mathrm{Si} 2 \mathrm{p}, \mathrm{C} 1 \mathrm{~s}, \mathrm{Al} 2 \mathrm{p}, \mathrm{Na} 1 \mathrm{~s}, \mathrm{Ca} 2 \mathrm{p}$, and $\mathrm{Fe} 2 \mathrm{p}_{3}$ (Figure 2(a)), whereas XPS examination of the surface of the nZVI coated pumice showed increased iron content. Also B 1s element, resulting from the use of $\mathrm{NaBH}_{4}$ during coating, has also been observed. According to the XPS results, atomic iron content increased from $0.8 \%$ to $3.3 \%$ after coating. The silicon content on the surface was observed to fall down from $17 \%$ to $2 \%$. These results are consistent with the results obtained from the SEM-EDS analysis and show that the applied coating has been successful. The binding energy center of the Fe $2 \mathrm{p}_{3}$ peak is $710 \mathrm{eV}$ (Figure 2(b)). However, Zhang et al. [26] argued that the peak observed at $710 \mathrm{eV}$ belonged to the Fe $2 \mathrm{p}_{2} \mathrm{p}_{3 / 2}$. This shows that iron is in the form of magnetite $\left(\mathrm{Fe}_{3} \mathrm{O}_{4}\right)[36,44,45]$. The center of the $\mathrm{O}$ 1s peak is $530 \mathrm{eV}$. Karabelli et al. [36] stated that the $\mathrm{O} 1 \mathrm{~s}$ peak in $\mathrm{Fe}_{3} \mathrm{O}_{4}$ ranges between 529.7 and $530.1 \mathrm{eV}$. This led to the conclusion that $\mathrm{O} 1 \mathrm{~s}$ peak observed at $530 \mathrm{eV}$ arises from $\mathrm{Fe}_{3} \mathrm{O}_{4}$. The binding energies of other elements in the pumice are Si 2p $103 \mathrm{eV}$ and 2s $154 \mathrm{eV}, \mathrm{Al} 2 \mathrm{p} 74 \mathrm{eV}$ and 2s $121 \mathrm{eV}, \mathrm{Cl}$ 


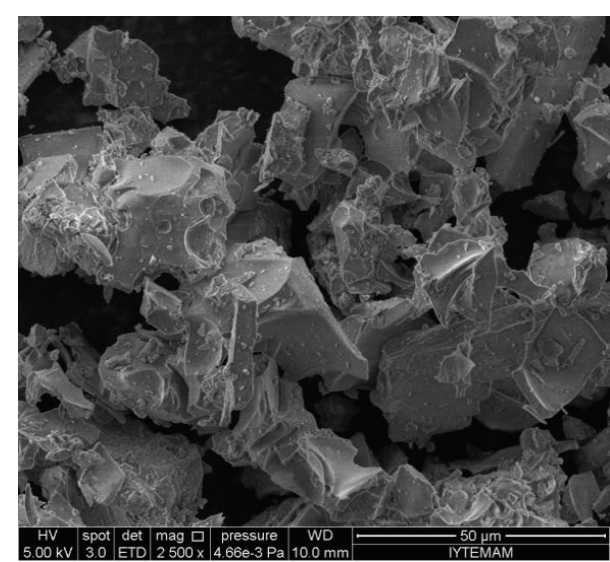

(a)

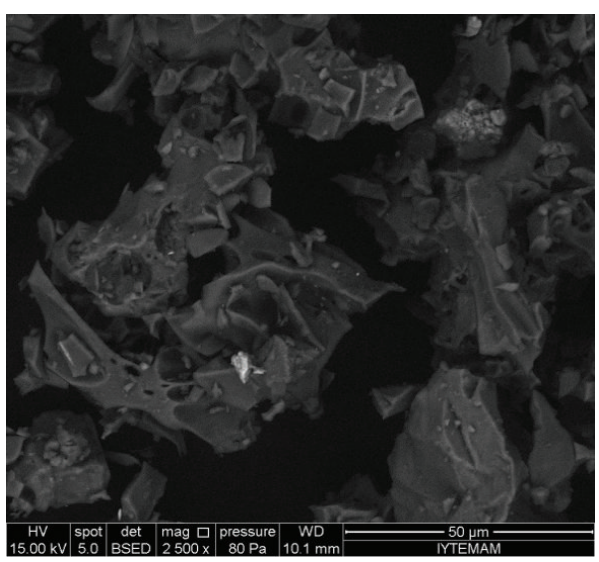

(c)

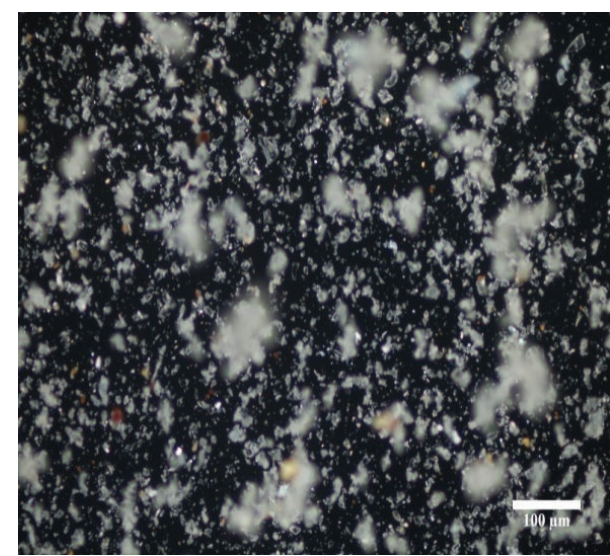

(e)

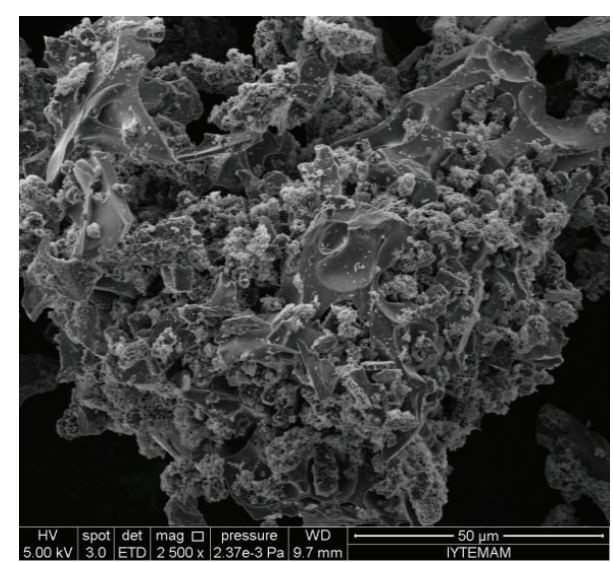

(b)

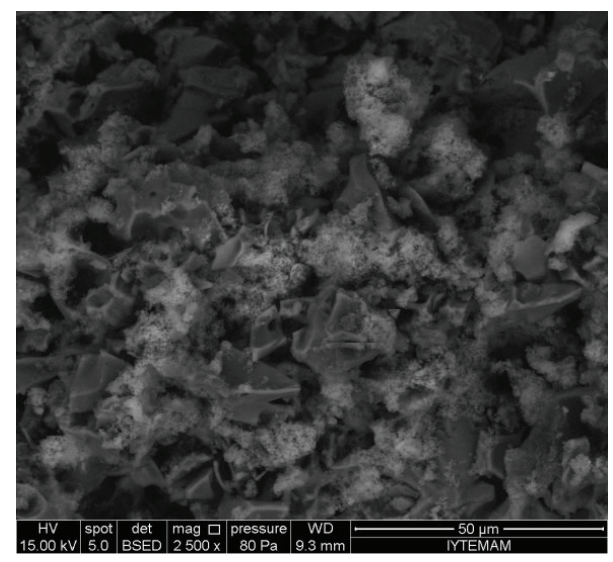

(d)

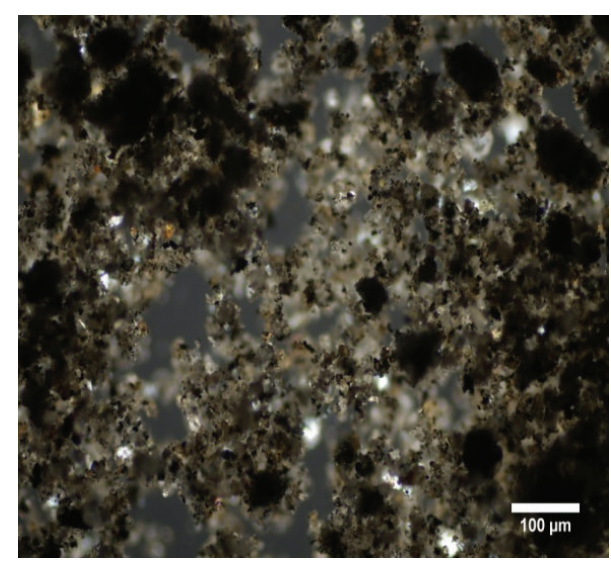

(f)

FIGURE 1: SEM images of bare pumice in different magnifications and detectors (a and c) and P-nZVI (b and d). Bare pumice (e) and P-nZVI (f) images obtained using PLM.

$2 \mathrm{p}_{3 / 2} 199 \mathrm{eV}$, and C 1s $286 \mathrm{eV}$ [26, 46-48]. Zhang et al. [26] in a study that they conducted stated that iron oxide shell was observed on the surface of nZVI. The thickness of this shell varies depending on the ZVI oxidation [40]. Thus, iron oxide resulting from partial oxidation of the ZVI has been detected with XPS on the surface of the nVZI coated pumice. Similarly, most of researchers detected iron oxide on the shell of $\mathrm{Fe}^{0}$ core [49-52]. Consequently, iron content $\left(\mathrm{Fe}^{0} / \mathrm{Fe}_{2} \mathrm{O}_{3} /\right.$ $\mathrm{Fe}_{3} \mathrm{O}_{4}$ ) of modified materials provided enhanced copper removal via adsorption/oxidation.

3.1.3. BET, Zeta Potential, and FTIR Analysis. The surface areas of the bare pumice and nZVI coated pumice were determined with BET- $\mathrm{N}_{2}$ method. All adsorption-desorption 


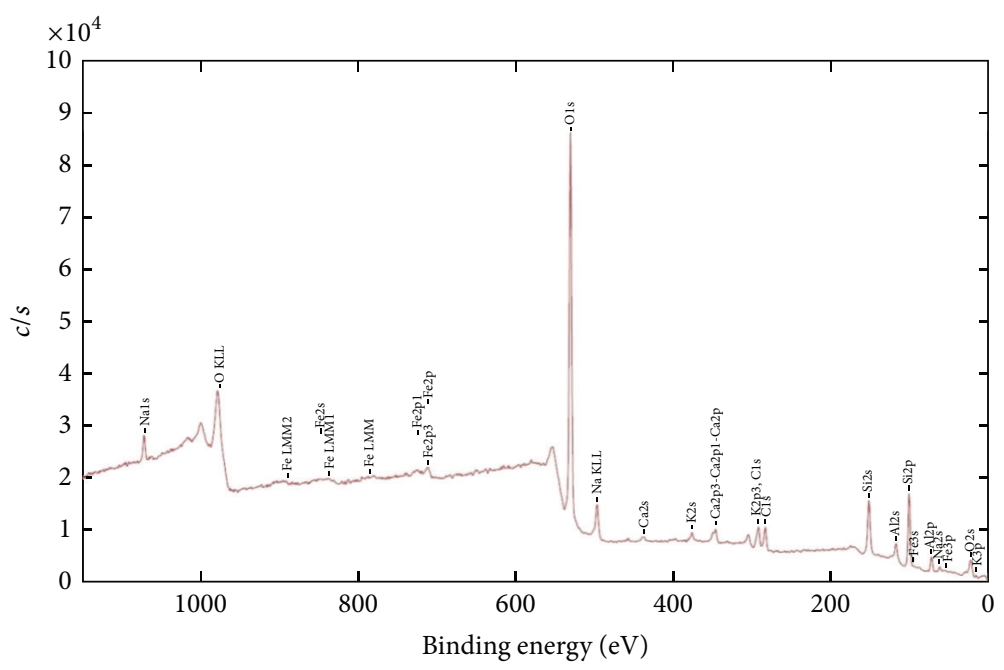

(a)

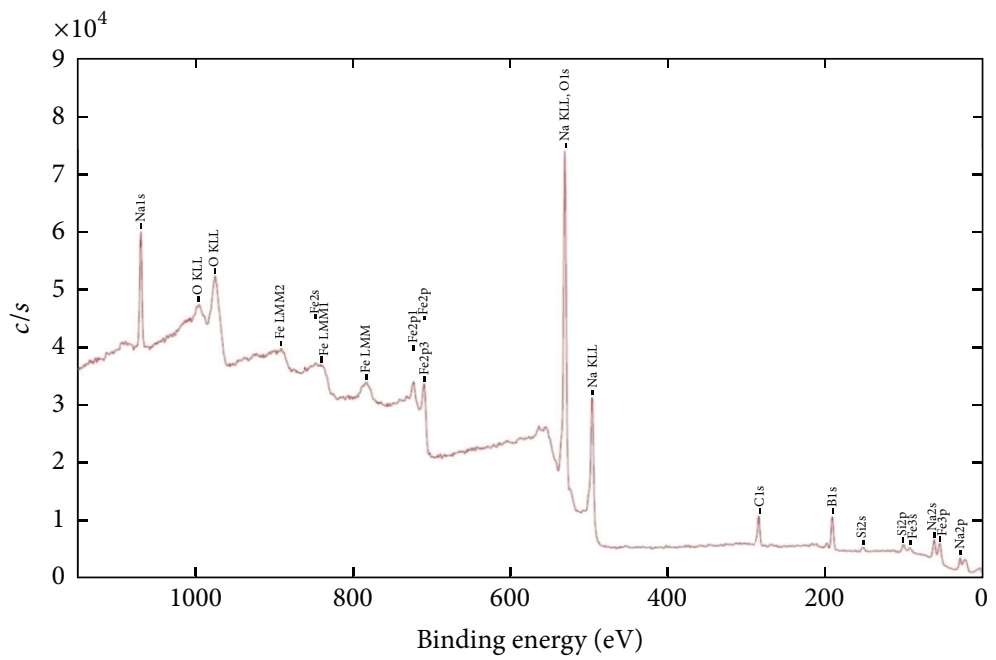

(b)

FIGURE 2: XPS spectrums of bare pumice (a) and P-nZVI (b).

results were shown in Table 2. The surface areas of bare pumice were 2.0 and $2.7 \mathrm{~m}^{2} / \mathrm{g}$ of Langmuir and BET adsorption isotherms, respectively. After coating with the nZVI, pumice surface area expanded $\left(5.9 \mathrm{~m}^{2} / \mathrm{g}\right)$ approximately 3 times. Furthermore, Lai et al. [53] stated that the iron coating of sand enhanced the surface area from $0.85 \mathrm{~m}^{2} / \mathrm{g}$ to $2.76 \mathrm{~m}^{2} / \mathrm{g}$. Similarly, Üzüm et al. [32] reported that the surface area of synthesized kaolinite-nZVI material was $6.9 \mathrm{~m}^{2} / \mathrm{g}$. Despite this lower surface area of P-nZVI compared to nZVI alone $\left(30-55 \mathrm{~m}^{2} / \mathrm{g}\right)$, the highest removal efficiencies were observed with the lowest dosage of P-nZVI. This phenomenon can be explained as follows: nZVI becomes easily oxidized and aggregated due to a higher specific surface area.

Determining the isoelectric points (IEP) value of the material tested in this study is very important. This is because the desired pollutant adsorption is affected by electrostatic interactions taking place between particle surfaces and the contaminant load. The IEPs of bare pumice have been measured as 2.73 (Figure 3(a)). Tunç and Duman [54] determined
TABLE 2: BET analysis results of bare pumice and P-nZVI.

\begin{tabular}{lcc}
\hline & Bare pumice & P-nZVI \\
\hline BET surface area $\left(\mathrm{m}^{2} / \mathrm{g}\right)$ & 2.0 & 5.90 \\
Langmuir surface area $\left(\mathrm{m}^{2} / \mathrm{g}\right)$ & 2.72 & 7.83 \\
$t$-plot external surface area & 2.56 & 6.60 \\
Average pore size $(\mathrm{nm})$ & 9.20 & 18.20 \\
Pore volume $<1000 \AA\left(\mathrm{cm}^{3} / \mathrm{g}\right)$ & 0.9851 & 0.9844 \\
\hline
\end{tabular}

the IEP of pumice as $\mathrm{pH}$ 2.7. The IEPs of P-nZVI were determined by zeta potential measurements to be around $\mathrm{pH}$ of 3.2 (Figure 3(b)). This IEP value is significantly lower than the IEP value of nZVIs (around 7-9 [55]). nZVI enters into a reaction with cationic pollutants within wider $\mathrm{pH}$ ranges thanks to its low IEP, thus allowing the pollutant to be adsorbed and/or oxidized [32]. If the $\mathrm{pH}$ of solution is below the IEP, more thicker double layer can be observed because of electrostatic repulsion among the surface and the cations. 


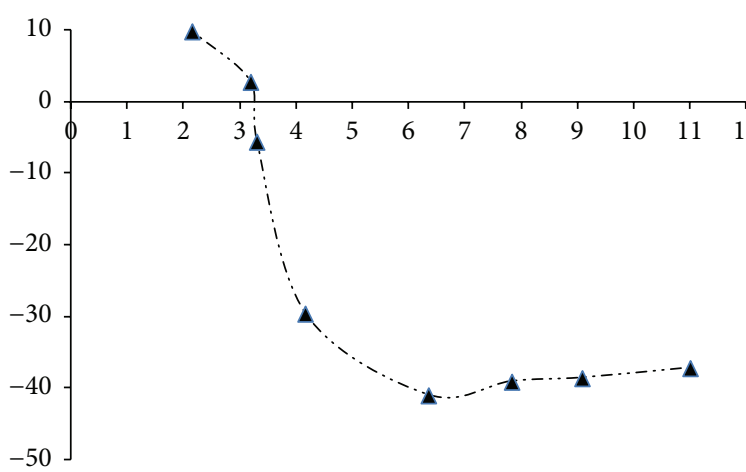

(a)

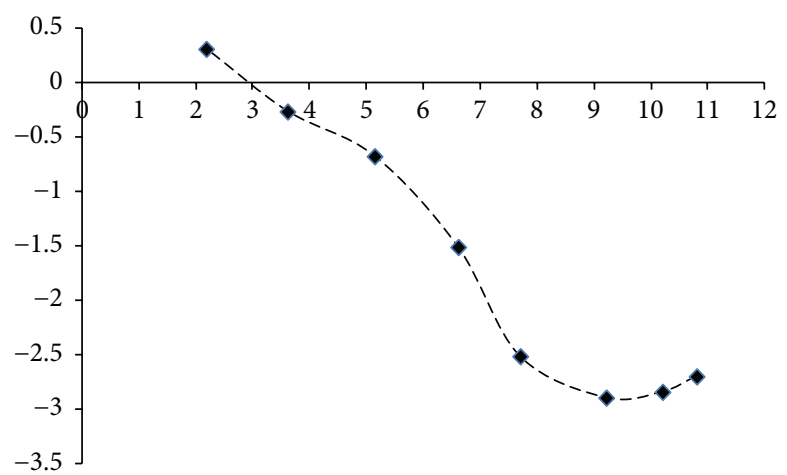

(b)

Figure 3: Zeta potential of spectrum of bare pumice (a) and P-nZVI (b).

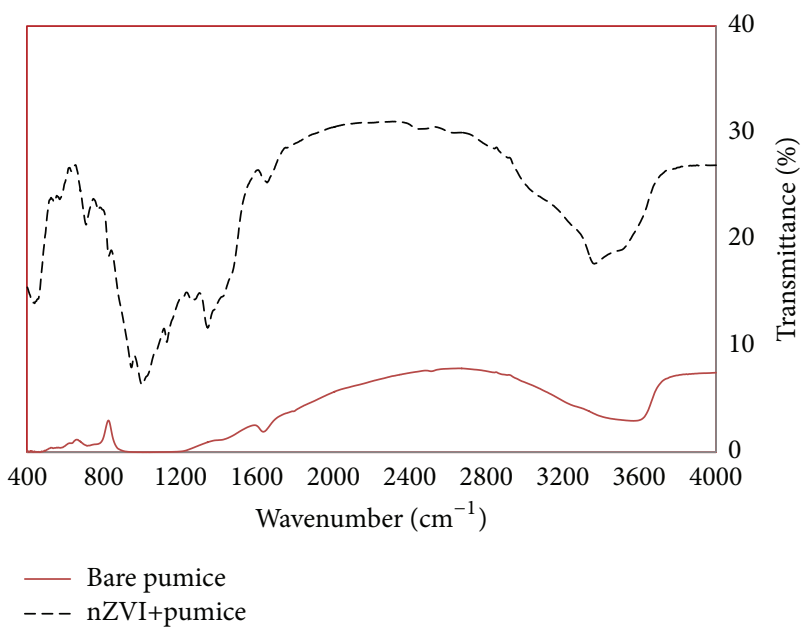

FIGURE 4: FTIR spectra of bare pumice and P-nZVI samples.

This situation is limited to the adsorption between the pollutant and the surface [56].

FTIR is an analysis method that can give information about the spectra of carboxyl, carbonyl, hydroxyl, amino, and other functional groups, as well as double and triple bonds. General screening was conducted on both bare pumice and nZVI coated pumice with FTIR spectrometer at wavelengths ranging between 400 and $4000 \mathrm{~cm}^{-1}$. Bare pumice and nZVI coated pumice spectra obtained via FTIR are shown in Figure 4 . When the spectra are compared, the changes in the adsorption peaks in the spectra belonging to the nZVI coated pumice are striking. The strongest adsorption peaks were observed at 3390,1356 , and $1319 \mathrm{~cm}^{-1}$. The strong peak at wavenumber $3390 \mathrm{~cm}^{-1}$ indicates hydroxyl groups. It is considered that this is due to the moisture content of the hydroxyl groups.

Moreover, the peak values at 455 and $589 \mathrm{~cm}^{-1}$ represent the Fe-O bonds [26]. These results are consistent with other characterization results in that they show nZVI and/or iron oxide accumulate in the surface of pumice. The adsorption peak between 660 and $790 \mathrm{~cm}^{-1}$ indicates that $\mathrm{Si}-\mathrm{O}$ and $\mathrm{Al}-\mathrm{O}$ bonds are broken by the reaction of $\mathrm{NaBH}_{4}$ and water $[57,58]$.
TABLE 3: Oxide composition of bare and P-nZVI using XRF results.

\begin{tabular}{lccccccc}
\hline & $\mathrm{SiO}_{2}$ & $\mathrm{Al}_{2} \mathrm{O}_{3}$ & $\mathrm{Na}_{2} \mathrm{O}$ & $\mathrm{Fe}_{2} \mathrm{O}_{3}$ & $\mathrm{~K}_{2} \mathrm{O}$ & $\mathrm{CaO}$ & $\mathrm{TiO}_{2}$ \\
\hline $\begin{array}{l}\text { Bare } \\
\text { pumice }\end{array}$ & $53.09 \%$ & $20.71 \%$ & $8.20 \%$ & $3.77 \%$ & $6.55 \%$ & $3.94 \%$ & $0.36 \%$ \\
P-nZVI & $33.95 \%$ & $18.01 \%$ & $17.62 \%$ & $17.02 \%$ & $6.56 \%$ & $2.56 \%$ & $0.37 \%$ \\
\hline
\end{tabular}

3.1.4. XRF and TGA Results. XRF analysis was performed on samples to determine the mineral composition of both bare pumice and nZVI coated pumice. Mineral oxide data obtained by the XRF is (weight \%) shown in Table 3. As can be seen from these results, $\mathrm{Fe}_{2} \mathrm{O}_{3}$ content of the nZVI coated pumice rises from $3.8 \%$ to as high as $17 \%$. This result indicated that the pumice was coated successfully with nZVI, being consistent with previous characterization results.

According to the thermal analysis results obtained from TGA performed under nitrogen gas and heated from 30 to $600^{\circ} \mathrm{C}$ at $10^{\circ} \mathrm{C} / \mathrm{min}$, a mass loss of $0.5 \%$ was observed in bare pumice, while the mass loss in nZVI coated pumice has been $7 \%$. The majority of the mass loss in nZVI coated pumice occurred at temperatures up to $200^{\circ} \mathrm{C}$. This result is due to the moisture content of the nZVI coated pumice sample. Mass loss has occurred as a result of the evaporation of water. The thermal stability of P-nZVI exhibited the good performance below $600^{\circ} \mathrm{C}$.

\subsection{Adsorption Tests}

3.2.1. Effect of nZVI Coating. The adsorption equilibrium time of copper in pure water was determined through kinetic tests performed with bare pumice and P-nZVI. Kinetic test results showed that copper can be removed in a very short time (10-30 $\mathrm{min}$ ) over $80 \%$. The adsorption time of 4 hours which is the duration in which the highest removal is achieved ( $>99 \%)$ has been selected as equilibrium time.

Isotherm tests have been performed to determine the effects of coating on the removal of copper. Both bare pumice and nZVI coated pumice were tested at $3000 \mathrm{ppb}$ copper concentrations $(0-3000 \mathrm{mg} / \mathrm{L}$ adsorbent dose). As it can be seen in Figure 5, the coating of pumice with nZVI significantly improved copper removal. While copper removal level 
TABLE 4: Adsorption capacities of pumice and P-nZVI.

Adsorption capacity ( $\mathrm{mg} \mathrm{Cu} / \mathrm{g}$ dose)

(Cu concentration: $3000 \mathrm{ppb}$, adsorbent dosage: $500 \mathrm{mg} / \mathrm{L})$

\begin{tabular}{lc}
\hline Bare pumice & 4.69 \\
P-nZVI & 1.19 \\
\hline
\end{tabular}

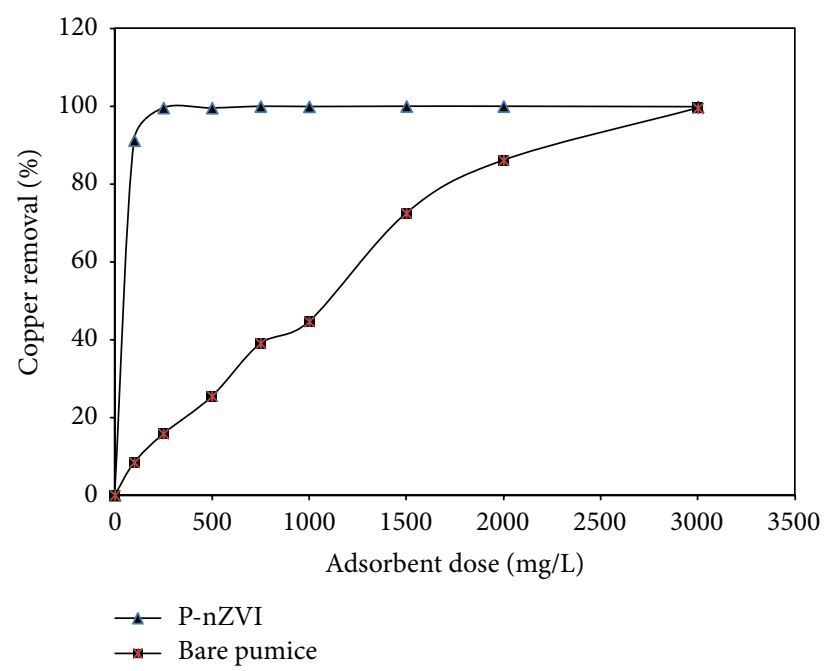

FIGURE 5: The effect of nZVI coating on copper removal (equilibrium time: $4 \mathrm{~h}$; temperature: $20^{\circ} \mathrm{C}, 150 \mathrm{rpm}$; $\mathrm{pH}$ : 8.0 ; copper concentration: $3000 \mathrm{ppb}$ ).

achieved in tests performed with $100 \mathrm{mg} / \mathrm{L}$ bare pumice dose was limited to $8 \%$, a copper removal level of over $90 \%$ has been achieved with the same dose of P-nZVI. Equilibrium adsorption capacities ( $q_{e}: \mathrm{mg} \mathrm{Cu}$ uptake per $\mathrm{g}$ adsorbent) were determined for all tested particles using the isotherm data. Adsorption capacity was calculated according to the following equation:

$$
q_{e}=\frac{\left(C_{0}-C_{e}\right) V}{D}
$$

where $q_{e}$ is the capacity of copper adsorbed at equilibrium, $C_{e}$ is the equilibrium solution phase copper concentration $(\mathrm{mg} / \mathrm{L}), C_{0}$ is the initial copper concentration $(\mathrm{mg} / \mathrm{L}), V$ is the solution volume (L), and $D$ is the adsorbent dosage (g).

Maximum copper adsorption capacity obtained by $\mathrm{P}$ nZVI was 4.69 (mg Cu/g adsorbent) at $500 \mathrm{mg} / \mathrm{L}$ adsorbent dosage and $3000 \mathrm{ppb}$ copper concentration. The adsorption capacities of bare pumice and P-nZVI were given in Table 4. Considering that the $\mathrm{Fe}^{0}$ and iron oxide surfaces on the pumice surface are $3.3 \%$ atomically (XPS data), the significantly high removal level achieved with P-nZVI shows that the coating has been successful. It is possible to speak of two mechanisms that provide copper removal: (i) adsorption of copper by iron oxide on the pumice surface and (ii) the oxidation of $\mathrm{Cu}^{2+}$ by the $\mathrm{Fe}^{0}$ surfaces on the surface of the pumice to $\mathrm{Cu}^{0}$. Based on the characterization data, it appears that the surface area of P-nZVI expanded. This makes the removal

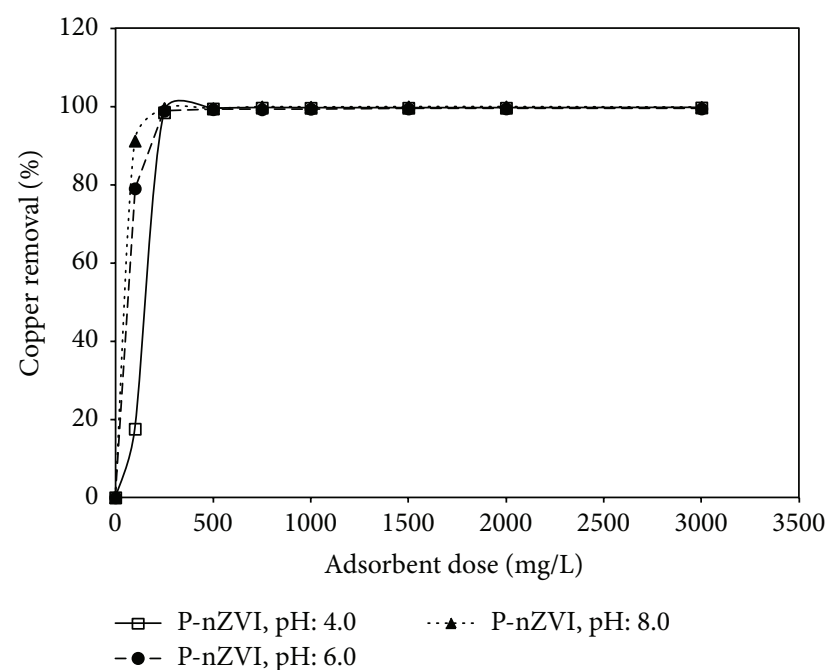

FIGURE 6: The effect of solution $\mathrm{pH}$ on copper removal (equilibrium time: $4 \mathrm{~h}$; temperature: $20^{\circ} \mathrm{C}, 150 \mathrm{rpm}$; copper concentration: $3000 \mathrm{ppb})$.

rates improve. Having a higher surface area compared to bare pumice, as expected, P-nZVI delivers a higher removal performance.

3.2.2. Effect of Solution $p H$. To determine the effect of solution $\mathrm{pH}$ on copper removal, three different $\mathrm{pH}$ values were tested (4.0,6.0, and 8.0). $\mathrm{pH}$ adjusting values were made with $\mathrm{HCl}$ and $\mathrm{NaOH}$. The copper removal levels achieved with P-nZVI are close to each other and high for all $\mathrm{pH}$ levels (>90\%) (Figure 6). As a result, there was no $\mathrm{pH}$ effect on copper removal. In control experiments that were conducted, no copper leaching was detected even at $\mathrm{pH}$ 4. The zeta potential of the P-nZVI can be shown as the reason for high level of removal at all $\mathrm{pH}$ values. That is to say all the tested $\mathrm{pH}$ levels for P-nZVI (whose IEP = 3.2) are above IEP, and the P-nZVI surface is negatively charged. Thus, $\mathrm{Cu}^{2+}$ interacts with pumice surface and $\mathrm{Cu}^{+2}$ is adsorbed onto the pumice surface. Used adsorbent samples collected after the tests were leached under acidic conditions and copper analyses were performed on the samples with ICP-MS. The highest copper levels were detected in P-nZVI. While the amount of copper found in the adsorbent after the removal test with bare pumice was $330 \mathrm{mg} / \mathrm{kg}$, a 4 times higher copper content of $1200 \mathrm{mg} / \mathrm{kg}$ copper was detected in the P-nZVI sample. This result proves that one of the removal mechanisms is adsorption.

3.2.3. Effect of Solution Background. In order to test the effect of natural organic matter (NOM) and background impurities on copper removal, tests were performed by injecting $3000 \mathrm{ppb}$ copper into natural surface water resource and humic acid isolate purchased from Acros Organics (Figure 7). The highest removal has been achieved in the solution prepared in distilled water containing only copper. The NOM possessing a hydrophilic character and other impurities in the natural water somewhat reduced the amount of copper 


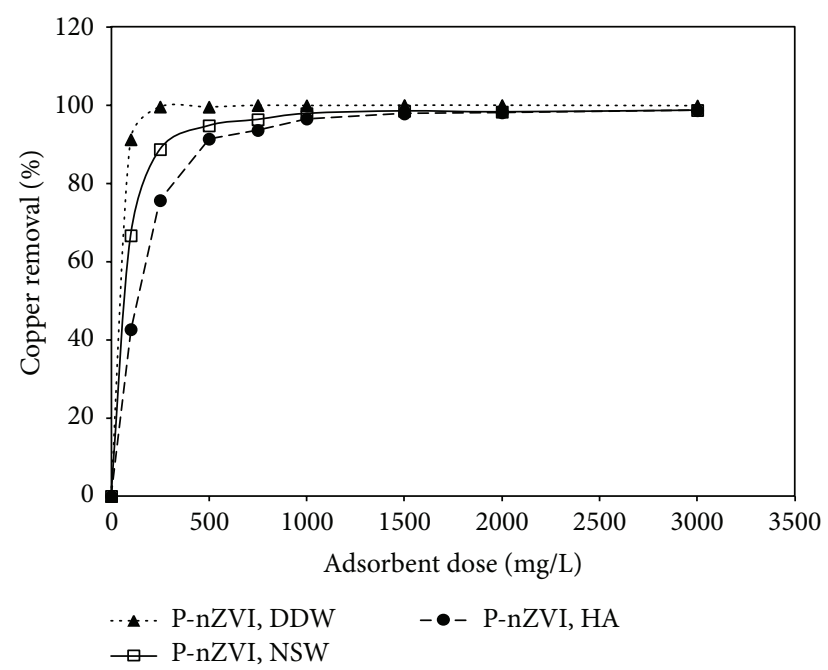

FIGURE 7: The effect of impurities of solution on copper removal (equilibrium time: $4 \mathrm{~h}$; temperature: $20^{\circ} \mathrm{C}$; shaking: $150 \mathrm{rpm}$; $\mathrm{pH}$ : 8.0; copper concentration: $3000 \mathrm{ppb}$ ).

removal. The lowest copper removal was achieved in the humic acid (HA) solution. Humic acid $\left(\mathrm{SUVA}_{254}>\right.$ $4 \mathrm{~L} / \mathrm{mg} \cdot \mathrm{m}$ ) has a more hydrophobic character than natural water $\left(\mathrm{SUVA}_{254}<2 \mathrm{~L} / \mathrm{mg} \cdot \mathrm{m}\right)$ and has a tendency to be adsorbed more by P-nZVI. The NOM possessing a hydrophobic character competes with copper and reduces the amount of copper removal. At higher P-nZVI doses however (>1000 mg/L), the type of water supply appeared to have no effect on copper removal. The results of these tests showed that P-nZVI, even in small doses, can remove copper which can be found in natural waters.

\section{Conclusions}

In this study, pumice which is used as a support material was coated with nZVI and was tested as an adsorbent for copper removal. The results were summarized as follows.

(i) Pumice was coated successfully with nZVI. P-nZVI was characterized in detail. The characterization results revealed the increase in $\mathrm{nZVI} /$ iron oxide content of pumice, which was detected using characterization methods such as SEM-EDS, XPS, and XRF.

(ii) nZVI coating increased the surface area of raw pumice, and increasing the specific pumice surface area was important factor since more adsorbing sites became available.

(iii) Copper removal tests were carried out with P-nZVI. $100 \mathrm{mg} / \mathrm{L}$ dose of P-nZVI has achieved 90\% removal at $3000 \mathrm{ppb}$ copper concentration.

(iv) A significant difference in copper removal efficiency for all tested $\mathrm{pH}$ values has not been observed.

(v) Detection of high copper content in samples collected after the tests proves that the primary copper removal mechanism of P-nZVI is adsorption. (vi) Removal tests were performed with the model copper solution and by adding copper to two different waters (model NOM and natural surface water resource) possessing different $\mathrm{SUVA}_{254}$ values. The lowest removal among the tested model solutions was achieved in humic acid solution. The reason for this is that the organic substance in waters with a high $\mathrm{SUVA}_{254}$ value has a higher absorbability to nZVI surfaces. Therefore, NOM partially competed with copper and reduced copper removal slightly more compared to model copper and natural spring water.

As a conclusion, it is considered that P-nZVI can be used as an alternative to other adsorbents as P-nZVI has a high level of copper removal, and pumice can easily be supplied as a naturally occurring material. By using this adsorbent, it will be possible to eliminate the disadvantages of other adsorbents with expensive manufacturing costs and utilize inexpensive natural materials. Also, P-nZVI, prepared in this study, can be directly injected into groundwater containing high copper and the desired removal can be achieved. Moreover, P-nZVI not only plays an important role in terms of copper removal, but also can be used effectively in the removal of the other heavy metals (nickel, zinc, cadmium, etc.). In the next phase which will be the continuation of this study, the possibility of the regeneration and the reuse of the prepared P-nZVI, competitive adsorption will be investigated.

\section{Competing Interests}

The authors declare that there is no conflict of interests.

\section{Authors' Contributions}

The paper was primarily written by Bilgehan I. Harman and all the authors contributed to the tests.

\section{References}

[1] A. H. Sulaymon, B. A. Abid, and J. A. Al-Najar, "Removal of lead copper chromium and cobalt ions onto granular activated carbon in batch and fixed-bed adsorbers," Chemical Engineering Journal, vol. 155, no. 3, pp. 647-653, 2009.

[2] J.-M. Zhu, T. M. Johnson, R. B. Finkelman, B.-S. Zheng, I. Sýkorová, and J. Pešek, "The occurrence and origin of selenium minerals in Se-rich stone coals, spoils and their adjacent soils in Yutangba, China," Chemical Geology, vol. 330-331, pp. 27-38, 2012.

[3] A. Adamczuk and D. Kołodyńska, "Equilibrium, thermodynamic and kinetic studies on removal of chromium, copper, zinc and arsenic from aqueous solutions onto fly ash coated by chitosan," Chemical Engineering Journal, vol. 274, pp. 200-212, 2015.

[4] E. Gimeno-García, V. Andreu, and R. Boluda, "Heavy metals incidence in the application of inorganic fertilizers and pesticides to rice farming soils," Environmental Pollution, vol. 92, no. 1, pp. 19-25, 1996.

[5] M. R. Awual, M. Ismael, T. Yaita et al., "Trace copper(II) ions detection and removal from water using novel ligand modified composite adsorbent," Chemical Engineering Journal, vol. 222, pp. 67-76, 2013. 
[6] M. R. Awual, I. M. M. Rahman, T. Yaita, M. A. Khaleque, and M. Ferdows, "PH dependent $\mathrm{Cu}(\mathrm{II})$ and $\mathrm{Pd}(\mathrm{II})$ ions detection and removal from aqueous media by an efficient mesoporous adsorbent," Chemical Engineering Journal, vol. 236, pp. 100-109, 2014.

[7] Z. Ö. Kocabaş-Atakli and Y. Yürüm, "Synthesis and characterization of anatase nanoadsorbent and application in removal of lead, copper and arsenic from water," Chemical Engineering Journal, vol. 225, pp. 625-635, 2013.

[8] R. Molinari, P. Argurio, and T. Poerio, "Studies of various solid membrane supports to prepare stable sandwich liquid membranes and testing copper(II) removal from aqueous media," Separation and Purification Technology, vol. 70, no. 2, pp. 166172, 2009.

[9] J. Bertinato and M. R. L'Abbé, "Maintaining copper homeostasis: regulation of copper-trafficking proteins in response to copper deficiency or overload," Journal of Nutritional Biochemistry, vol. 15, no. 6, pp. 316-322, 2004.

[10] Y.-H. Chan, J. Chen, Q. Liu, S. E. Wark, D. H. Son, and J. D. Batteas, "Ultrasensitive copper(II) detection using plasmonenhanced and photo-brightened luminescence of cdse quantum dots," Analytical Chemistry, vol. 82, no. 9, pp. 3671-3678, 2010.

[11] Turkish Ministry of Health, Regulation Concerning Water Intended for Human Consumption (Revision 2013), Official News Paper no. 28580, Turkish Ministry of Health, Ankara, Turkey, 2013.

[12] US EPA, "National primary drinking water regulations," Document EPA 816-F-09-004, US EPA, 2009.

[13] M. R. Awual, "A novel facial composite adsorbent for enhanced copper(II) detection and removal from wastewater," Chemical Engineering Journal, vol. 266, pp. 368-375, 2015.

[14] M. A. Tofighy and T. Mohammadi, "Copper ions removal from water using functionalized carbon nanotubes-mullite composite as adsorbent," Materials Research Bulletin, vol. 68, pp. 54-59, 2015.

[15] A. Jusoh, L. S. Shiung, N. Ali, and M. J. M. M. Noor, "A simulation study of the removal efficiency of granular activated carbon on cadmium and lead," Desalination, vol. 206, no. 1-3, pp. 9-16, 2007.

[16] Y. Li, F. Liu, B. Xia et al., "Removal of copper from aqueous solution by carbon nanotube/calcium alginate composites," Journal of Hazardous Materials, vol. 177, no. 1-3, pp. 876-880, 2010.

[17] Z. Ö. Kocabaş and Y. Yürüm, "Kinetic modeling of arsenic removal from water by ferric ion loaded red mud," Separation Science and Technology, vol. 46, no. 15, pp. 2380-2390, 2011.

[18] M. F. Sawalha, J. R. Peralta-Videa, M. Duarte-Gardea, and J. L. Gardea-Torresdey, "Removal of copper, lead, and zinc from contaminated water by saltbush biomass: analysis of the optimum binding, stripping, and binding mechanism," Bioresource Technology, vol. 99, no. 10, pp. 4438-4444, 2008.

[19] J. S. Yamani, S. M. Miller, M. L. Spaulding, and J. B. Zimmerman, "Enhanced arsenic removal using mixed metal oxide impregnated chitosan beads," Water Research, vol. 46, no. 14, pp. 4427-4434, 2012.

[20] M. Kitis, S. S. Kaplan, E. Karakaya, N. O. Yigit, and G. Civelekoglu, "Adsorption of natural organic matter from waters by iron coated pumice," Chemosphere, vol. 66, no. 1, pp. 130-138, 2007.

[21] T. Liu, Z.-L. Wang, and Y. Sun, "Manipulating the morphology of nanoscale zero-valent iron on pumice for removal of heavy metals from wastewater," Chemical Engineering Journal, vol. 263, pp. 55-61, 2015.
[22] M. Yavuz, F. Gode, E. Pehlivan, S. Ozmert, and Y. C. Sharma, "An economic removal of $\mathrm{Cu}^{2+}$ and $\mathrm{Cr}^{3+}$ on the new adsorbents: pumice and polyacrylonitrile/pumice composite," Chemical Engineering Journal, vol. 137, no. 3, pp. 453-461, 2008.

[23] W.-X. Zhang, "Nanoscale iron particles for environmental remediation: an overview," Journal of Nanoparticle Research, vol. 5, no. 3-4, pp. 323-332, 2003.

[24] J. T. Nurmi, P. G. Tratnyek, V. Sarathy et al., "Characterization and properties of metallic iron nanoparticles: spectroscopy, electrochemistry, and kinetics," Environmental Science and Technology, vol. 39, no. 5, pp. 1221-1230, 2005.

[25] J. Xiao, Q. Yue, B. Gao et al., "Performance of activated carbon/nanoscale zero-valent iron for removal of trihalomethanes (THMs) at infinitesimal concentration in drinking water," Chemical Engineering Journal, vol. 253, pp. 63-72, 2014.

[26] X. Zhang, S. Lin, Z. Chen, M. Megharaj, and R. Naidu, "Kaolinite-supported nanoscale zero-valent iron for removal of $\mathrm{Pb}^{2+}$ from aqueous solution: reactivity, characterization and mechanism," Water Research, vol. 45, no. 11, pp. 3481-3488, 2011.

[27] Q. Du, S. Zhang, B. Pan, L. Lv, W. Zhang, and Q. Zhang, "Bifunctional resin-ZVI composites for effective removal of arsenite through simultaneous adsorption and oxidation," Water Research, vol. 47, no. 16, pp. 6064-6074, 2013.

[28] Y. Su, J. Lu, and H. Chen, “The genus Leucophenga (Diptera, Drosophilidae), part I: the abbreviata species group from the Oriental region with morphological and molecular evidence," Zootaxa, vol. 3637, no. 3, pp. 361-373, 2013.

[29] Y. Zhang, Y. Li, J. Li, L. Hu, and X. Zheng, "Enhanced removal of nitrate by a novel composite: nanoscale zero valent iron supported on pillared clay," Chemical Engineering Journal, vol. 171, no. 2, pp. 526-531, 2011.

[30] L.-N. Shi, X. Zhang, and Z.-L. Chen, "Removal of Chromium(VI) from wastewater using bentonite-supported nanoscale zero-valent iron," Water Research, vol. 45, no. 2, pp. 886892, 2011.

[31] S. E. Shaibu, F. A. Adekola, H. I. Adegoke, and O. S. Ayanda, "A comparative study of the adsorption of methylene blue onto synthesized nanoscale zero-valent iron-bamboo and manganese-bamboo composites," Materials, vol. 7, no. 6, pp. 44934507, 2014.

[32] Ç. Üzüm, T. Shahwan, A. E. Eroğlu, K. R. Hallam, T. B. Scott, and I. Lieberwirth, "Synthesis and characterization of kaolinitesupported zero-valent iron nanoparticles and their application for the removal of aqueous $\mathrm{Cu}^{2+}$ and $\mathrm{Co}^{2+}$ ions," Applied Clay Science, vol. 43, no. 2, pp. 172-181, 2009.

[33] M. Kitis and S. S. Kaplan, "Advanced oxidation of natural organic matter using hydrogen peroxide and iron-coated pumice particles," Chemosphere, vol. 68, no. 10, pp. 1846-1853, 2007.

[34] T. Liu, Z.-L. Wang, X. Yan, and B. Zhang, "Removal of mercury (II) and chromium (VI) from wastewater using a new and effective composite: pumice-supported nanoscale zero-valent iron," Chemical Engineering Journal, vol. 245, pp. 34-40, 2014.

[35] S. M. Ponder, J. G. Darab, and T. E. Mallouk, "Remediation of $\mathrm{Cr}(\mathrm{VI})$ and $\mathrm{Pb}(\mathrm{II})$ aqueous solutions using supported, nanoscale zero-valent iron," Environmental Science and Technology, vol. 34, no. 12, pp. 2564-2569, 2000.

[36] D. Karabelli, S. Ünal, T. Shahwan, and A. E. Eroĝlu, "Preparation and characterization of alumina-supported iron nanoparticles and its application for the removal of aqueous $\mathrm{Cu}^{2+}$ ions," Chemical Engineering Journal, vol. 168, no. 2, pp. 979-984, 2011. 
[37] R. Fu, Y. Yang, Z. Xu, X. Zhang, X. Guo, and D. Bi, "The removal of chromium (VI) and lead (II) from groundwater using sepiolite-supported nanoscale zero-valent iron (SNZVI)," Chemosphere, vol. 138, pp. 726-734, 2015.

[38] M. Mosaferi, S. Nemati, A. Khataee, S. Nasseri, and A. A. Hashemi, "Removal of Arsenic (III, V) from aqueous solution by nanoscale zero-valent iron stabilized with starch and carboxymethyl cellulose," Journal of Environmental Health Science and Engineering, vol. 12, no. 1, article 74, 2014.

[39] S. A. Kim, S. Kamala-Kannan, K.-J. Lee et al., "Removal of Pb(II) from aqueous solution by a zeolite-nanoscale zero-valent iron composite," Chemical Engineering Journal, vol. 217, pp. 54-60, 2013.

[40] H.-Y. Shu, M.-C. Chang, C.-C. Chen, and P.-E. Chen, "Using resin supported nano zero-valent iron particles for decoloration of Acid Blue 113 azo dye solution," Journal of Hazardous Materials, vol. 184, no. 1-3, pp. 499-505, 2010.

[41] X. Zhang, S. Lin, X.-Q. Lu, and Z.-L. Chen, "Removal of Pb(II) from water using synthesized kaolin supported nanoscale zerovalent iron," Chemical Engineering Journal, vol. 163, no. 3, pp. 243-248, 2010.

[42] N. O. Yigit and S. Tozum, "Removal of selenium species from waters using various surface-modified natural particles and waste materials," Clean-Soil, Air, Water, vol. 40, no. 7, pp. 735$745,2012$.

[43] Y. Xi, M. Mallavarapu, and R. Naidu, "Reduction and adsorption of $\mathrm{Pb}^{2+}$ in aqueous solution by nano-zero-valent iron-A SEM, TEM and XPS study," Materials Research Bulletin, vol. 45, no. 10, pp. 1361-1367, 2010.

[44] T. B. Scott, G. C. Allen, P. J. Heard, and M. G. Randell, "Reduction of U(VI) to U(IV) on the surface of magnetite," Geochimica et Cosmochimica Acta, vol. 69, no. 24, pp. 56395646, 2005.

[45] G. C. Allen, M. T. Curtis, A. J. Hooper, and P. M. Tucker, "X-ray photoelectron spectroscopy of iron-oxygen systems," Journal of the Chemical Society Dalton Transactions, vol. 14, pp. 1525-1530, 1974.

[46] Y.-P. Sun, X.-Q. Li, J. Cao, W.-X. Zhang, and H. P. Wang, "Characterization of zero-valent iron nanoparticles," Advances in Colloid and Interface Science, vol. 120, no. 1-3, pp. 47-56, 2006.

[47] C. D. Wagner, W. M. Riggs, L. E. Davis, and J. F. Moulder, Handbook of X-ray Photoelectron Spectroscopy, Perkin-Elmer Corporation, Physical Electronics Division, Eden Prairie, Minn, USA, 1979.

[48] K. C. Lombardi, A. S. Mangrich, F. Wypych, U. P. RodriguesFilho, J. L. Guimarães, and W. H. Schreiner, "Sequestered carbon on clay mineral probed by electron paramagnetic resonance and X-ray photoelectron spectroscopy," Journal of Colloid and Interface Science, vol. 295, no. 1, pp. 135-140, 2006.

[49] L. Ling, B. Pan, and W.-X. Zhang, "Removal of selenium from water with nanoscale zero-valent iron: mechanisms of intraparticle reduction of Se(IV)," Water Research, vol. 71, pp. 274281, 2015.

[50] Y. Fu, L. Peng, Q. Zeng et al., "High efficient removal of tetracycline from solution by degradation and flocculation with nanoscale zerovalent iron," Chemical Engineering Journal, vol. 270, pp. 631-640, 2015.

[51] W. Yan, H.-L. Lien, B. E. Koel, and W.-X. Zhang, "Iron nanoparticles for environmental clean-up: recent developments and future outlook," Environmental Sciences: Processes \& Impacts, vol. 15, no. 1, pp. 63-77, 2013.
[52] W. Yan, R. Vasic, A. I. Frenkel, and B. E. Koel, "Intraparticle reduction of arsenite (As (III)) by nanoscale zerovalent iron (nZVI) investigated with in situ X-ray absorption spectroscopy," Environmental Science \& Technology, vol. 46, no. 13, pp. 70187026, 2012.

[53] C. H. Lai, S. L. Lo, and H. L. Chiang, "Adsorption/desorption properties of copper ions on the surface of iron-coated sand using BET and EDAX analyses," Chemosphere, vol. 41, no. 8, pp. 1249-1255, 2000.

[54] S. Tunç and O. Duman, "Effects of electrolytes on the electrokinetic properties of pumice suspensions," Journal of Dispersion Science and Technology, vol. 30, no. 4, pp. 548-555, 2009.

[55] Y.-T. Lin, C.-H. Weng, and F.-Y. Chen, "Effective removal of AB24 dye by nano/micro-size zero-valent iron," Separation and Purification Technology, vol. 64, no. 1, pp. 26-30, 2008.

[56] M. Arshadi, M. Soleymanzadeh, J. W. L. Salvacion, and F. SalimiVahid, "Nanoscale Zero-Valent Iron (NZVI) supported on sineguelas waste for $\mathrm{Pb}(\mathrm{II})$ removal from aqueous solution: kinetics, thermodynamic and mechanism," Journal of Colloid and Interface Science, vol. 426, pp. 241-251, 2014.

[57] P. Yuan, F. Annabi-Bergaya, Q. Tao et al., "Combined study by XRD, FTIR, TG and HRTEM on the structure of delaminated Fe-intercalated/pillared clay," Journal of Colloid and Interface Science, vol. 324, no. 1-2, pp. 142-149, 2008.

[58] R. L. Frost and U. Jonansson, "Combination bands in the infrared spectroscopy of kaolins-a drift spectroscopic study," Clays and Clay Minerals, vol. 46, no. 4, pp. 466-477, 1998. 

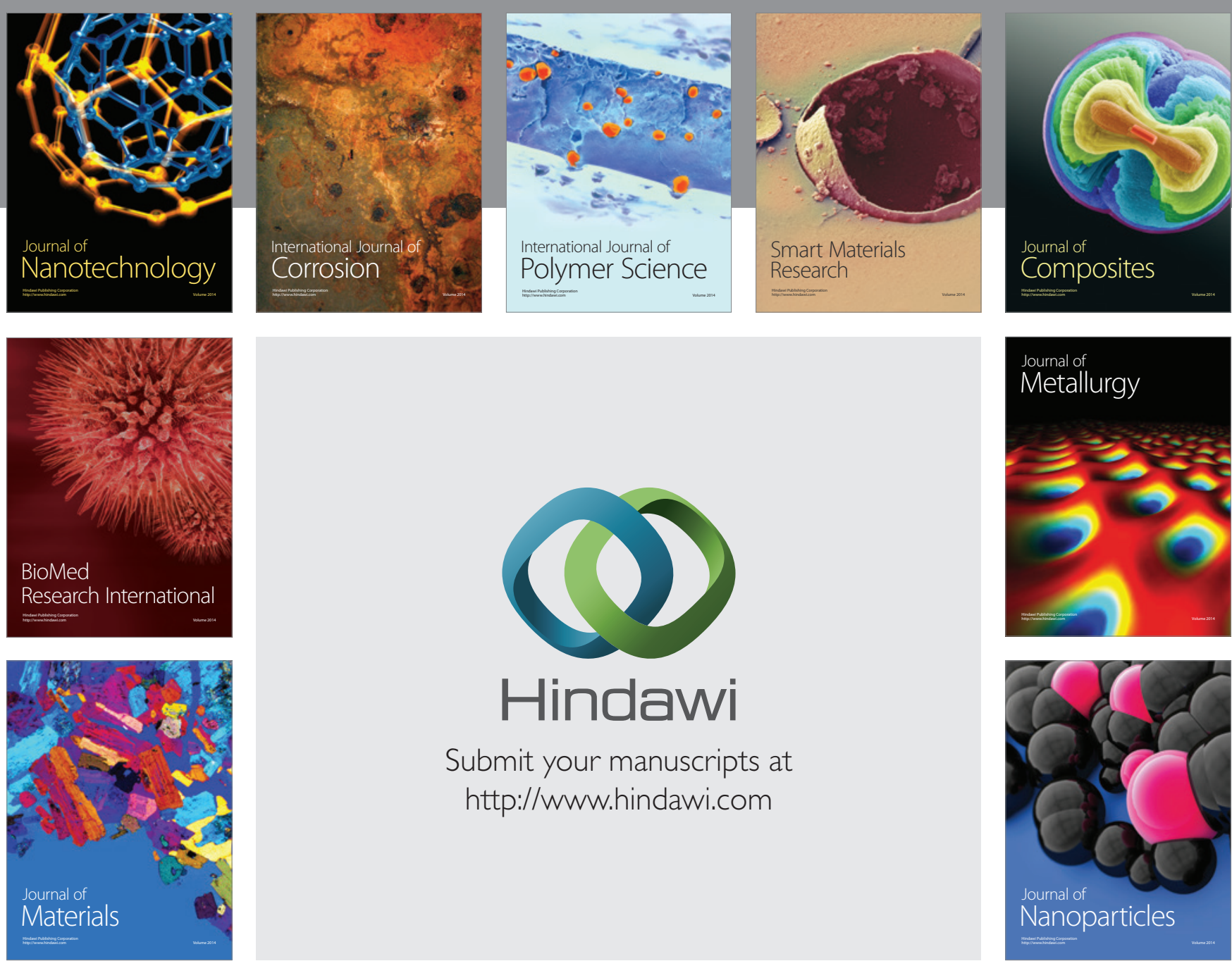

\section{Hindawi}

Submit your manuscripts at

http://www.hindawi.com

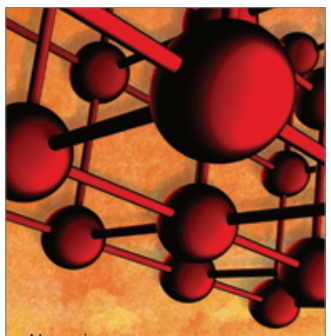

Materials Science and Engineering
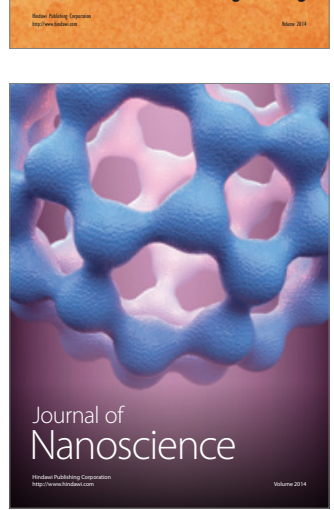
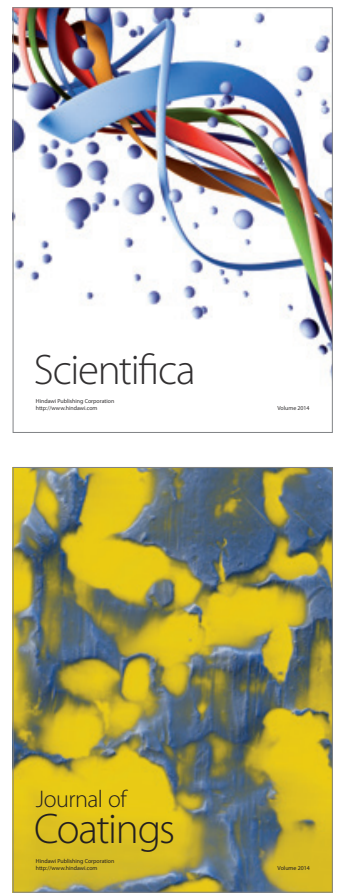
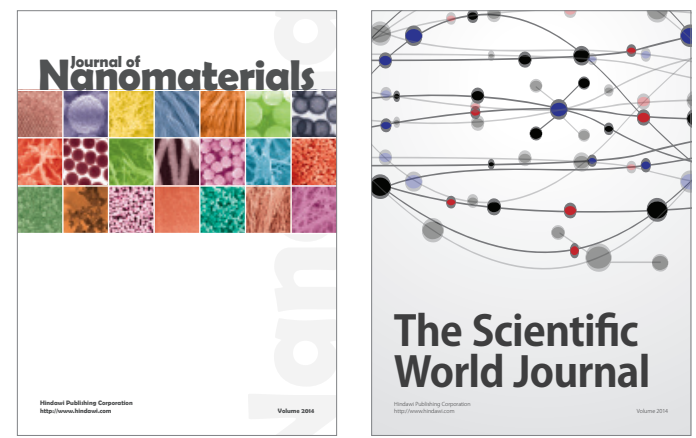

The Scientific World Journal
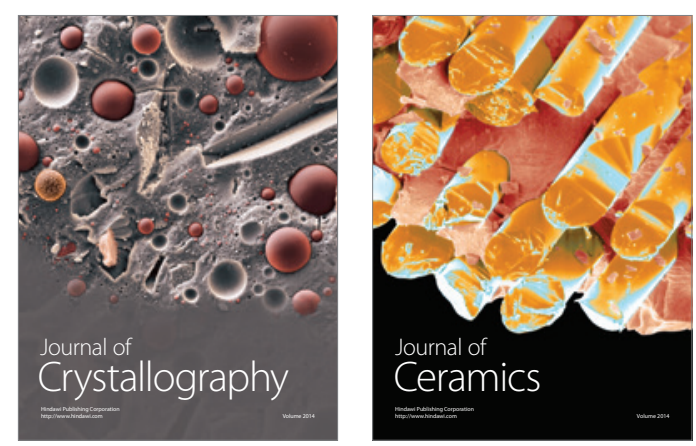
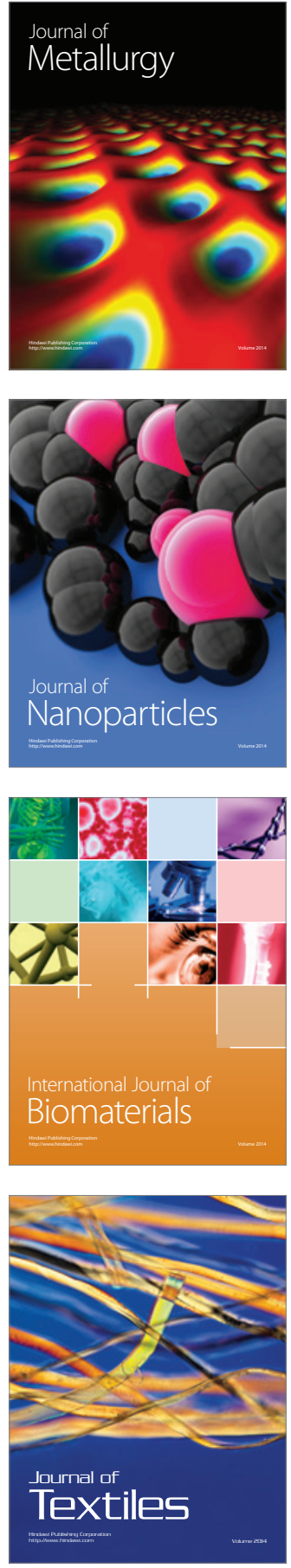